\title{
Fate and survival of microbial pest control agents in nontarget aquatic organisms*
}

\author{
Fred J. Genthner ${ }^{1}$, Steven S. Foss ${ }^{1}$, Robert P. Campbell ${ }^{2, * *}$, John W. Fournie ${ }^{1}$ \\ ${ }^{1}$ U.S. Environmental Protection Agency, Environmental Research Laboratory, Gulf Breeze, Florida 32561, USA \\ ${ }^{2}$ Technical Resources, Inc., 1 Sabine Island Drive, Gulf Breeze, Florida 32561, USA
}

\begin{abstract}
A fully enclosed test system was developed both to assess potential adverse effects of microbial pest control agents on nontarget aquatic invertebrates and to monitor their fate and survival. Eastern oysters Crassostrea virginica were exposed to various microbial pest control agents including the vegetative bacterium Pseudomonas fluorescens, bacterial spores of Bacillus sphaericus, and fungal spores of Colletotrichum gloeosporioides $\mathrm{f}$. sp. aeschynomene. After an exposure of $3 \mathrm{~d}$ for the fungus, $14 \mathrm{~d}$ for the bacterial spores, and $7 \mathrm{~d}$ for the vegetative bacterial cells, half the oysters were placed into a fully enclosed $60 \mathrm{l}$ aquarium equipped with a recirculating water system which passed water through an ultraviolet-irradiation sterilizer at a rate of $1 \mathrm{l} \mathrm{min}-1$. The remaining oysters were placed into wire cages maintained in Santa Rosa Sound, Pensacola, Florida, USA. Plate counts, performed on homogenized oyster tissues, revealed that all of the microbial pest control agents were found in oysters after exposure. Oysters depurated each microorganism at a different rate. None of the agents colonized the oysters. For all microbes tested, rates of clearance from the oysters in the enclosed UV light depuration system were similar to rates of clearance from the oysters in Santa Rosa Sound. Histological examination of oyster tissues detected P. fluorescens and B. sphaericus in the gut and C. gloeosporioides in the gill. Spore germination was not observed and no apparent signs of infectivity or pathogenicity were detected.
\end{abstract}

\section{INTRODUCTION}

Recent advances in the development of genetically engineered microbial pest control agents (MPCAs) have created the need for additional nontarget test protocols; particularly, those in which the test organism can be fully contained (Anderson \& Harvey 1992). Previous studies have used static exposure systems to determine effects of MPCAs on nontarget organisms (Couch et al. 1984, 1985, Foss et al. 1986, Fournie et al. 1988). Though effective for evaluating infectivity and pathogenicity, these approaches provided no information concerning fate and survival of the MPCAs in the test systems or organisms. Thus, questions regarding colonization of the animal by the MPCA or rate of clearance could not be fully addressed.

- Contribution No. 808, Environmental Research Laboratory, U.S. EPA, Gulf Breeze

- Present address: Department of Biology, The University of West Florida, Pensacola, Florida 32514, USA
Flow-through laboratory systems or field studies could be used to obtain such information; however, problems of containment arise when working with genetically engineered MPCAs. To address the containment problem, we adapted a commercial shellfish cleansing process called 'depuration'. In this, oysters are held in tanks of seawater which are sterilized by physical or chemical means (Son \& Fleet 1980). The widely used ultraviolet irradiation (UV) method was selected (Wood 1961) to sterilize the seawater for depuration. By adjusting water temperature and salinity to that of Santa Rosa Sound and the rate of water circulation through the sterilizer, we were able to fieldvalidate this system with 3 disparate MPCAs, thereby establishing a fully contained system for studying fate of MPCAs and their effects on the eastern oyster.

The present study describes results of the development, laboratory testing, and field-validation of an enclosed, single species test system for determining both fate and effects of MPCAs using the eastern oyster Crassostrea virginica as a nontarget invertebrate. The 
oyster, described by Lightner et al. (1989) as an excellent nontarget organism for MPCA testing, has been successfully used for this purpose (Fournie et al. 1988, Yousten et al. 1991).

We tested 3 different microorganisms. vegetative bacteria Pseudomonas fluorescens; bacterial spores Bacillus sphaericus 2362; and fungal spores Colletotrichum gloeosporioides $\mathrm{f}$. $\mathrm{sp}$. aeschynomene (Cga). All 3 are representative MPCAs. A strain of $P$ fluorescens, marketed as Dagger ${ }^{\otimes}$, was registered in 1988 by the Environmental Protection Agency (EPA) to control seedling 'damping off' disease in cotton. $B$. sphaericus 2362 was recently reg-

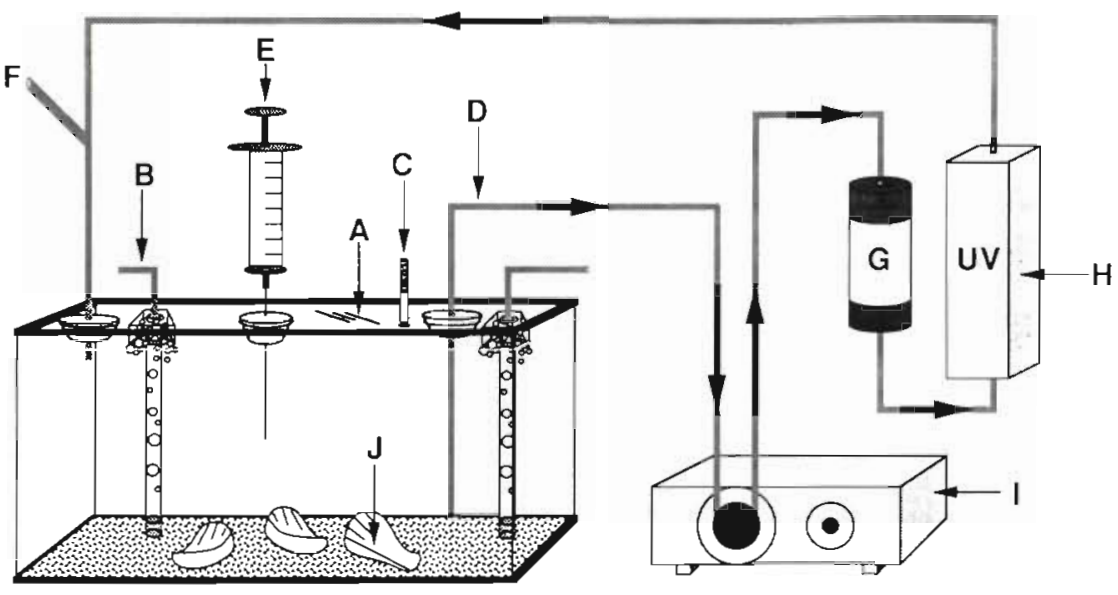
istered by the EPA as a mosquito larvicide. Cga, marketed as Collego ${ }^{\circledR}$, is an EPA-registered postemergent herbicide now being applied to rice and soybean fields to control the northern jointvetch weed Aeschynomene virginica.

\section{MATERIALS AND METHODS}

Microorganisms and culture conditions. Pseudomonas fluorescens FG-2, used as a surrogate for the Dagger ${ }^{\oplus}$ strain, and selected for spontaneous resistance to $500 \mu \mathrm{g} \mathrm{ml}^{-1}$ nalidixic acid (Nx) and $75 \mu \mathrm{g} \mathrm{ml}^{-1}$ rifampicin (Rif), was derived from $P$. fluorescens PF015 (R. Olsen, Univ. of Michigan). Pure cultures, started from a single colony inoculum, were grown to late log phase by incubation for $18 \mathrm{~h}\left(30^{\circ} \mathrm{C}\right)$ with shaking (200 rpm) in $500 \mathrm{ml}$ Erlenmeyer flasks containing $200 \mathrm{ml}$ of Luria-Bertani (LB) broth (Maniatis et al. 1982). Cells were harvested by centrifugation ( $8000 \times$ g) and washed once in sterile seawater prior to use as inoculum. P. fluorescens was enumerated by plate count on Pseudomonas F Agar (PsF, Difco) made selective by the addition of $500 \mu \mathrm{g} \mathrm{ml} \mathrm{m}^{-1}$ of $\mathrm{Nx}$ (PsF $+\mathrm{Nx}$ ). $B$. sphaericus $2362-7$ was cultured, enumerated and the inoculum prepared as described by Yousten et al. (1991). Cga, obtained from the commercial product Collego ${ }^{(9)}$, was cultured at $30^{\circ} \mathrm{C}$ on TA medium (TeBeest \& Weidemann 1990).

Conidiospore inoculum was prepared by scraping the surface of sporulating cultures produced after a $5 \mathrm{~d}$

\footnotetext{
- Mention of commercial products or company names does not imply endorsement by the U.S. Environmental Protection Agency
}

incubation on TA agar plates. Spores were washed once in sterile seawater. Cga was enumerated on Martins medium containing $200 \mu \mathrm{g} \mathrm{ml}^{-1}$ streptomycin, $40 \mu \mathrm{g} \mathrm{ml} \mathrm{m}^{-1}$ chloramphenicol and $50 \mu \mathrm{g} \mathrm{m} \mathrm{m}^{-1}$ nystatin (TeBeest 1982).

Cfu $\mathrm{ml}^{-1}$ or Cfu $\mathrm{g}^{-1}$ dry weight of oyster tissue represent the mean of triplicate determinations for which the standard deviation was within $20 \%$ of the mean.

Exposure of oysters to MPCAs. Oysters were collected and maintained as described previously (Yousten et al. 1991). For exposure, 40 oysters were removed from the holding tanks, cleaned with a wire brush and placed in $60 \mathrm{l}$ aquaria. The aquaria were equipped with under-gravel filters covered with crushed coral and filled with artificial seawater. Water was maintained at a salinity of $15 \pm 5 \%$ and at a temperature of $15 \pm 5^{\circ} \mathrm{C}$. Oysters, fed a mixture of $3 \mathrm{ma}$ rine algae (Lightner et al. 1989) every other day, were allowed to acclimate to laboratory conditions for $1 \mathrm{wk}$ before addition of the MPCA. Aquaria were sealed with a plexiglass top and secured with adhesive tape. The MPCA was added directly to the aquarium through an inoculation port. A water sample was removed after $15 \mathrm{~min}$ and at varying intervals thereafter to determine the titer of the MPCA. Oysters were removed for sampling at varying intervals after inoculation. Oyster shells were cleaned with $10 \%$ bleach solution, rinsed in sterile water, and cross sections of oyster tissue were removed. Approximately $2 \mathrm{~g}$ of the oyster tissue were placed in a ground-glass tissue homogenizer. Homogenates were prepared in $5 \mathrm{ml}$ of sterile seawater Numbers of MPCAs in the oyster homogenates were determined by spread-plating appropriate dilutions on the selective media described previously. 
All dilutions were made in sterile seawater. Cross sections through whole oyster tissue were also processed for routine paraffin histology (Luna 1968).

Clearance of MPCAs from oyster and field validation. After an exposure of $3 \mathrm{~d}$ for Cga spores, $7 \mathrm{~d}$ for Pseudomonas fluorescens cells and $14 \mathrm{~d}$ for Bacillus sphaericus spores, half of the oysters were placed into the enclosed, UV light, depuration aquarium (Fig. 1). The remaining oysters were secured in wire cages $(12 \times 20 \mathrm{~cm}, 2$ to 5 per cage $)$ and placed on the bottom of Santa Rosa Sound in a depth of approximately $2.5 \mathrm{~m}$. At the beginning of the clearance phase the salinity and temperature of the aquarium water were adjusted to the conditions in Santa Rosa Sound. During clearance the temperature of the sound varied by $2^{\circ} \mathrm{C}$ while the salinity varied by $5 \%$. The lid contained ports for air, water circulation and sampling. An external crushed oyster shell filter, required for $\mathrm{pH}$ control, was housed in a canister fashioned from PVC pipe [3 inch $(=7.6 \mathrm{~cm})$ diam. . Water pumped from the aquarium for sterilization passed first through the crushed oyster shell filter then the UV sterilizer before returning to the aquarium. A Masterflex ${ }^{(B)}$ variable speed drive pump (50 to 600 rpm range) equipped with Tygon ${ }^{(B)}$ (R-303) tubing (size 15 or $4.8 \mathrm{~mm}$ wall size) and used for water circulation was set at a flow rate of $11 \mathrm{~min}^{-1}$ An Aquafine $^{(1)}$ Ultraviolet Water Sterilizer (Model SP-2, $118 \mathrm{VAC}, 60 \mathrm{~Hz}$ ), capable of treating $90 \mathrm{l}$ of water $\mathrm{min}^{-1}$, was used to kill the MPCAs. Oysters were removed at varying intervals and analyzed as described above.

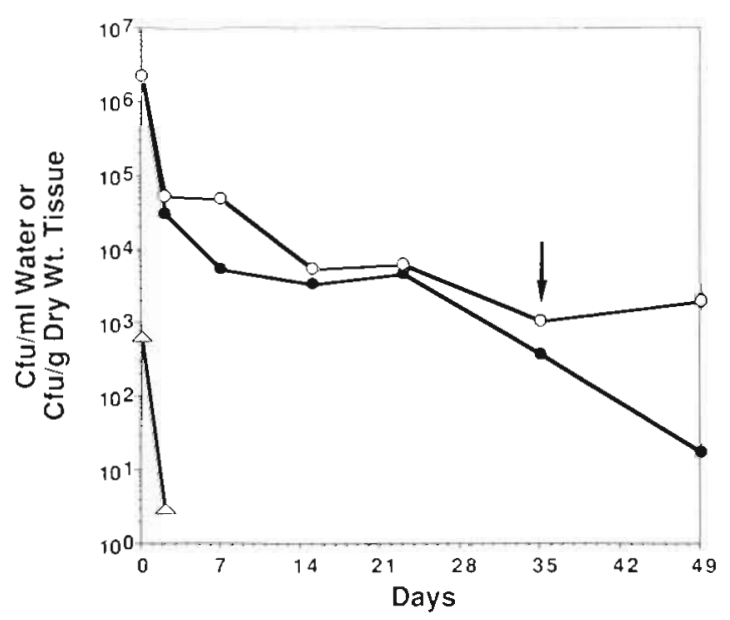

Fig. 2. Elimination of Pseudomonas fluorescens cells from oysters Crassostrea virginica during depuration in the enclosed

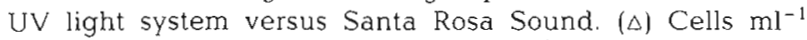
water in the enclosed system; (o) cells $\mathrm{g}^{-1}$ dry wt. tissue from oysters depurated in the enclosed system; ( cells $\mathrm{g}^{-1}$ dry wt. tissue from oysters depurated in Santa Rosa Sound. Arrow denotes time at which the recirculating pump permanently malfunctioned

\section{RESULTS}

Pseudomonas fluorescens was added to the exposure aquarium at an initial cell density of $6.3 \times 10^{7} \mathrm{cfu} \mathrm{m}^{-1}$. After $7 \mathrm{~d}$ of exposure the $P$. fluorescens cell density in the water column had declined to $1 \times 10^{3} \mathrm{cfu} \mathrm{ml} \mathrm{ml}^{-1}$ whereas the $P$. fluorescens cells had attained densities in the oysters of $2.3 \times 10^{6} \mathrm{cfu}^{-1}$ dry weight. Histological examination of oyster tissue revealed that exposure to $P$. fluorescens apparently did not result in an infection or cause any pathological changes. An initial water sample taken $1 / 2 \mathrm{~h}$ after the $P$. fluorescens-exposed oysters were placed into the enclosed system showed $6.1 \times 10^{2}$ P. fluorescens cells $\mathrm{ml}^{-1}$ (Fig. 2). After $2 \mathrm{~d} P$. fluorescens were undetectable in the water column. During the first $35 \mathrm{~d}$, numbers of $P$. fluorescens cells cleared from the oysters at similar rates, regardless of whether the oysters were placed in Santa Rosa Sound or the enclosed system (Fig. 2). On the 35th day of depuration the recirculating pump malfunctioned and remained damaged beyond repair. As shown in Fig. 2 the numbers of the P. fluorescens cells in oysters which were placed in Santa Rosa Sound continued to decline at a constant rate from Day 35 until the termination of the experiment on Day 49. However, after the pump malfunctioned numbers of $P$. fluorescens cells in oysters held under static conditions in the system ceased to decline. From Day 35 to 49 there was a slight increase in $P$. fluorescens cell numbers from $1.1 \times 10^{3}$ to $2.0 \times 10^{3} \mathrm{cfu} \mathrm{g}^{-1}$ dry weight of oyster tissue (Fig. 2).

Bacillus sphaericus spores were added to the exposure aquarium at an initial density of $1.9 \times 10^{6} \mathrm{ml}^{-1}$. Histological examination of oyster tissue showed that B. sphaericus spores had not caused any apparent signs of infectivity or pathogenicity during the $14 \mathrm{~d}$ exposure period. Fig. 3a shows B. sphaericus spores in the digestive tract of exposed oysters. After $14 \mathrm{~d}$ in the exposure aquarium, the oysters which were placed into the enclosed depuration system contained $5.1 \times$ $10^{5}$ spores $\mathrm{g}^{-1}$ dry weight (Fig. 4). One day after addition of the contaminated oysters, the water in the enclosed system contained $2.5 \times 10^{4}$ spores $\mathrm{ml}^{-1}$. Numbers of spores in the water column declined to $<20 \mathrm{ml}^{-1}$ after $8 \mathrm{~d}$ of clearance and were undetectable at Day 22 (Fig. 4). Rates of spore clearance from oysters placed in either Santa Rosa Sound or the depuration system were similar; spores were undetectable in oyster tissue at Day 40 (Fig. 4).

Cga spores were added to the exposure aquarium at an initial density of $7 \times 10^{4} \mathrm{ml}^{-1}$. Three days after the oysters were placed into the exposure aquarium the numbers of spores in the water had declined to $9.5 \times$ $10^{2} \mathrm{ml}^{-1}$ while the numbers of spores in the oysters had risen to $1.7 \times 10^{5}$ spores $g^{-1}$ dry weight of tissue. Histological examination of oyster tissue showed that 


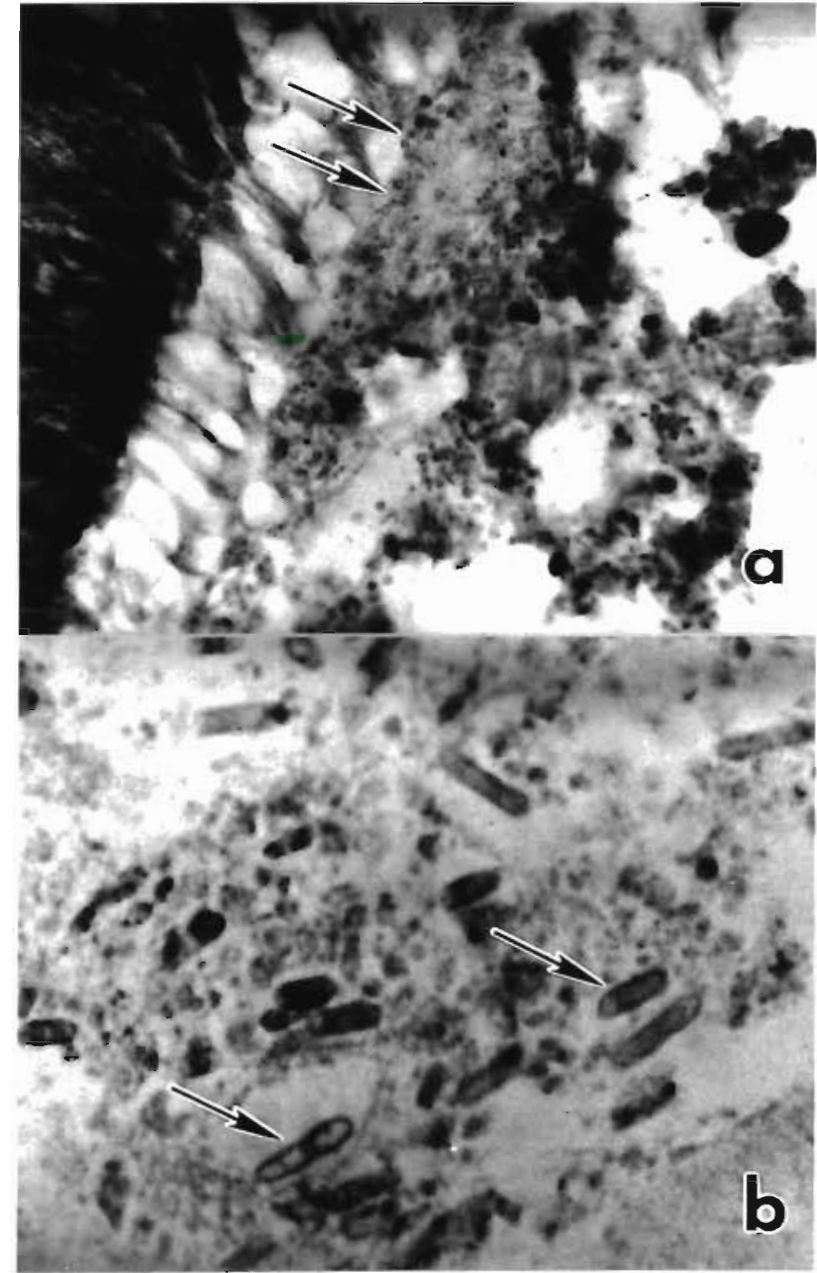

Fig. 3. Crassostrea virginica. Histological sections through eastern oysters. (a) Oysters exposed to Bacillus sphaericus spores for $14 \mathrm{~d}$; note spores (arrows) in lumen of digestive tract. $\times 2200$. (b) Oysters exposed to spores of Colletotrichum gloeosporioides f. sp. aeschynomene for $3 \mathrm{~d}$; note spores (arrows) in water tubes. $\times 2200$

the Cga spores had not germinated or caused detectable pathological changes. Fig. 3b shows Cga spores in a water tube of the oyster gill. Oysters exposed to Cga for $3 \mathrm{~d}$ and placed in either the clearance system or Santa Rosa Sound rid themselves of the fungal spores at similar rapid rates (Fig. 5). Cga spores were not detected in water sampled from the clearance system. In addition, Cga spores were undetectable in the oysters placed in Santa Rosa Sound or in the enclosed system. at 8 and $11 \mathrm{~d}$, respectively (Fig. 5). Water from uninoculated, control aquaria was periodically sampled to assure that indigenous microorganisms did not grow on the selective media. These results indicated that indigenous microbes did not interfere with our ability to accurately enumerate the 3 test microbes.

Tests were also conducted to confirm that the

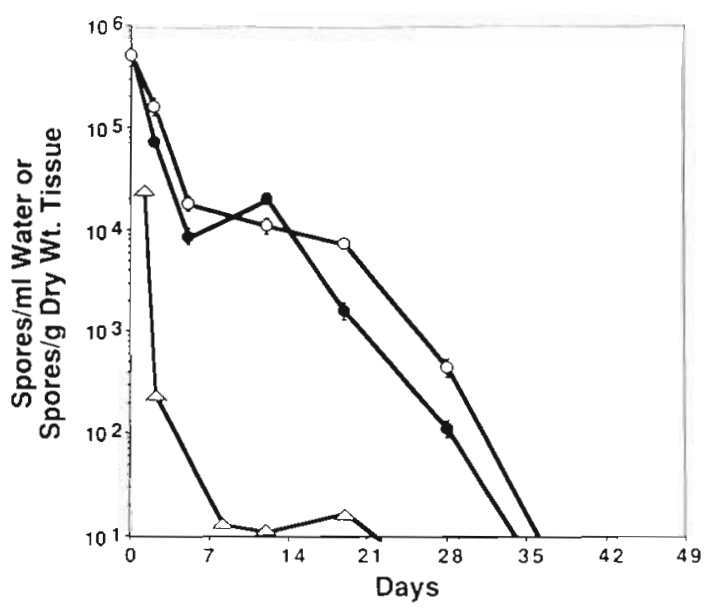

Fig. 4. Crassostrea virginica. Elimination of Bacillus sphaericus spores from oysters during depuration in the enclosed system versus Santa Rosa Sound. (A) Spores $\mathrm{ml}^{-1}$ of water in the enclosed UV light system; (o) spores $\mathrm{g}^{-1}$ dry wt tissue from oysters depurated in the enclosed UV light system; $(\bullet)$ spores $\mathrm{g}^{-1}$ dry wt tissue from oysters depurated in Santa Rosa Sound

aquaria prohibited MPCA release. Uncovered, selective media plates were positioned within $1 \mathrm{~m}$ of the aquaria for $1 \mathrm{~h}$ and swabs of equipment and nearby surfaces demonstrated that our system completely contained the test microorganisms.

During development of this enclosed laboratory system, several designs and strategies were tested. These included placing contaminated oysters in a static aquarium and replacing one-third the volume of water every third day or moving the oysters to a new

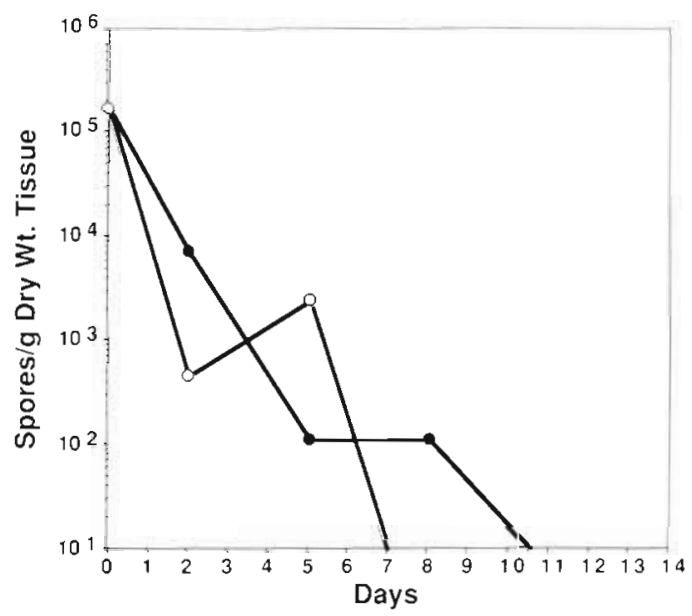

Fig. 5. Crassostrea virginica. Elimination of Colletotrichum gloeosporioides f. sp. aeschynomene spores from oysters during depuration in the enclosed system versus Santa Rosa Sound. (o) Spores $g^{-1}$ dry wt tissue from oyster depurated in the enclosed UV light system; (•) spores $\mathrm{g}^{-1}$ dry wt tissue from oysters depurated in Santa Rosa Sound 
static aquarium every third day. No strategy proved effective in simulating field conditions. In addition, containment of the test microbes using these strategies was severely compromised.

\section{DISCUSSION}

Depuration rates for the different microbial pest control agents varied. This finding is in agreement with the results of Son \& Fleet (1980) who reported differences in clearing rates of various bacterial pathogens from oysters. In our work, the very rapid rate of clearance of the fungal spores was probably as much a reflection of their limited survival in the aquatic environment (TeBeest 1982) as their clearance from the oyster. In contrast, the extended clearance times for the Bacillus sphaericus spores and Pseudomonas fluorescens cells may be due a combination of factors. At the onset of depuration, oysters were heavily contaminated with these agents and more heavily contaminated oysters have been shown to require longer cleansing times (Son \& Fleet 1980). It is also possible that the length of exposure might influence the rate of clearance with a lengthy exposure favoring longer clearance times due to the microbe becoming adsorbed within the digestive gland. Adsorption of bacteria in the oyster digestive tract was hypothesized by Buisson et al. (1981) to explain the 2-phase pattern of bacterial elimination from oysters during depuration (Figs. 2 \& 3) with weakly attached bacteria being eliminated first. Comprehensive studies of the microbial ecology of shellfish in relation to their marine environment are needed to better understand this phenomenon (Souness \& Fleet 1991)

The permanent malfunction of the recirculating pump during clearance of Pseudomonas fluorescens cells from the oysters (Fig. 2) provided a serendipitous control which indicated that continuous UV treatment of the water in the enclosed system was necessary for continued clearance of the contaminating bacterial cells from the animals. After the pump malfunction, the slight increase in numbers of $P$. fluorescens cells in the oysters was probably due to the re-ingestion of the test bacteria from the water column. Although complete clearance of $P$. fluorescens cells was not observed with oysters placed in Santa Rosa Sound for 7 wk (Fig. 2), we believe that with the continued clearance trend complete elimination of these cells would have been eventually achieved. Although histological examination of oyster tissue showed that none of the microbial pest control agents caused infection or any pathological changes, several microbial pathogens have been reported for oysters (Couch 1985).

Germination and colonization by the microbial pest control agents were not observed in oysters held in the laboratory or Santa Rosa Sound. This suggests that stresses in the natural environment did not influence fate of the MPCAs in the oysters. Although not observed in this study, colonization of the oyster by a released microbe should remain a distinct possibility. The microbial flora of the oyster is not merely a reflection of its surroundings; an endogenous microbial oyster flora exists. Vasconcelos \& Lee (1973) found the microbial composition of oysters subjected to ultraviolet light-treated seawater remained at levels comparable to the control oysters held in untreated seawater. Other investigations have reported the persistence of Vibrio species in shellfish exposed to UV-depuration systems (Greenberg et al. 1982, Eyles \& Davey 1984). Recently, Tamplin \& Capers (1992), using a UV light-depuration system, showed that Vibrio vulnificus was a persistent component of the microbial flora of oysters. The conclusion reached by Son \& Fleet (1980) was that oysters possessed the ability to selectively retain some microorganisms while eliminating others (Son \& Fleet 1980).

An enclosed laboratory exposure system was utilized to follow fate and survival of MPCAs both within the system and in nontarget organisms. Our design differed from previously described systems (Couch et al: 1984, 1985, Foss et al. 1986, Fournie et al. 1988) in that it was a totally enclosed, recirculating system. This design modification enabled us to address questions regarding fate which were impossible in previously designed systems. Specifically, we could use this system to determine whether the MPCA had colonized the oyster or to obtain data on the rate at which these microbes cleared from this aquatic invertebrate. We use 'colonization' in terms of the microbe establishing a commensal association with the oyster, persisting and growing within it.

Our field studies demonstrated that this fully enclosed system could be used to determine whether microbial pest control agents will colonize oysters or, if colonization does not occur, estimate the rate at which various MPCAs will clear from oysters in the natural environment. This system was intended to be of greatest value for evaluating hazards associated with release of genetically engineered microbial pest control agents since such microbes cannot be released without an experimental use permit (Experimental Use Permits 1988\}.

\section{LITERATURE CITED}

Anderson, R. L., Harvey, J. (1992). Procedures and concepts for evaluating effects of microbial pest control agents: a research coordination workshop. ERL-DUL-2686, U.S. EPA, Duluth, MN

Buisson, D. H., Fletcher, G. C., Begg, C. W. (1981). Bacterial 
depuration of the Pacific Oyster (Crassostrea gigas) in New Zealand. N.Z. J. Sci. 24: 253-262

Couch, J. A. (1985). Prospective study of infectious and noninfectious diseases in oysters and fishes in three Gulf of Mexico estuaries. Dis. aquat. Org. 1: 59-82

Couch, J. A., Foss, S. S., Courtney, L. A. (1985). Evaluation for risks of an insect virus, bacterium, and protozoan to a nontarget, estuarine crustacean. EPA/600/X-85/290, U.S. EPA, Gulf Breeze, FL

Couch, J. A., Martin, S. M., Tompkins, G., Kinney, J. (1984). A simple system for the preliminary evaluation of infectivity and pathogenesis of insect virus in a nontarget estuarine shrimp. J. Invertebr. Pathol. 43: 351-357

Eyles, M. J., Davey, G. R. (1984). Microbiology of commercial depuration of the Sydney rock oyster, Crassostrea commercialis. J. Food Prot. 47: 703-706

Experimental Use Permits (1988). Title 40, Code of Federal Regulations, Part 172. Government Printing Office, Washington, DC

Fournie, J. W., Foss, S. S., Couch, J. A. (1988). A multispecies system for evaluation of infectivity and pathogenicity of microbial pest control agents in nontargel aquatic species Dis. aquat. Org. 5: 63-70

Foss, S. S., Courtney, L. A., Couch, J. A. (1986). Evaluation of a fungal agent (Lagenidium giganteum) under development as an MPCA for nontarget risks. Report EPA/600/X86/229, U.S. EPA, Gulf Breeze, FL

Greenberg, E. P., Dubois, M., Palhof, B. (1982). The survival of marine vibrios in Merceneria mercenaria, the hardshell clam. J. Food Saf. 4: 113-123

Lightner, D. V., Thurman, R. B., Trumper, B. (1989). An enclosed aquatic multispecies test system for testing microbial pest control agents with nontarget species. EPA/600/4-89/027, U.S. EPA, Gulf Breeze, FL
Luna, L. G. (1968). Manual of histological staining methods of the Armed Forces Institute of Pathology, 3rd edn. McGraw-Hill, New York, p. 5, 32, 222

Maniatis, T., Fritsch, E. F., Sambrook, J. M. (1982). Molecular cloning: a laboratory manual. Cold Spring Harbor Laboratory, Cold Spring Harbor, NY

Son, N. T., Fleet, G. H. (1980). Behavior of pathogenic bacteria in the oyster, Crassostrea commercialis, during depuration, reiaying and storage. Appl, environ. Microbiol. 40: $994-1002$

Souness, R. A., Fleet, G. H. (1991). Bacterial agents in shellfish depuration. In: Otwell, W. S., Rodrick, G. E., Martin, R. E. (eds.) Molluscan shellfish depuration. CRC Press, Boca Raton, p. 59-70

Tamplin, M. L., Capers, G. M. (1992). Persistence of Vibrio vulnificus in tissues of Gulf Coast Oysters, Crassostrea virginica, exposed to seawater disinfected with UV light. Appl. environ. Microbiol. 58: 1506-1510

TeBeest, D. O. (1982). Survival of Colletotrichum gloeosporioides $\mathrm{f}$. sp. aeschynomene in rice irrigation water and soil. Plant Dis. 66: 469-472

TeBeest, D. O., Weidemann, G. J. (1990). Preparation and regeneration of protoplasts of Colletotrichum gloeosporioides f. sp. aeschynomene. Mycologia 82: 249-255

Vasconcelos, G. J., Lee, J. S. (1972). Microbial flora of Pacific oysters subjected to ultraviolet-irradiated seawater. Appl Microb. 23: 11-16

Wood, P C. (1961.\}. The principles of water sterilization by ultraviolet light and their application in the purification of oysters. Fishery Invest. 231-248

Yousten, A. A., Benfield, E. F., Campbell, R. P., Foss, S. S., Genthner, F. J. (1991). Fate of Bacillus sphaericus 2362 spores following ingestion by nontarget invertebrates. J. Invertebr. Pathol. 58: 427-435

Manuscript first received: October 5, 1992

Revised version accepted: April 14, 1993 